\title{
Young people in oncological treatment during COVID-19: indicators of the social representation of the coronavirus
}

Marina Maria Austregésilo Saraiva da Silva 1

iD https://orcid.org/0000-0003-0452-7021

Cybelle Cavalcanti Accioly 2

(iD) https://orcid.org/0000-0002-2890-4453

Ana Paula Amaral Pedrosa 3

D https://orcid.org/0000-0002-8137-0462

Stéphanie Maximiano de Azevedo 4

D https://orcid.org/0000-0003-3794-0058

Eliane Nóbrega Albuquerque 5

D https://orcid.org/0000-0003-1079-5970
Tatiany Lisiere Brandão Kunzler Lima 6

(iD) https://orcid.org/0000-0002-8234-7408

Maria Eduarda Pedrosa Bouçanova 7

(iD) https://orcid.org/0000-0001-9383-3228

1-3,5,6 Instituto de Medicina Integral Prof. Fernando Figueira. Rua dos Coelhos, 300. Boa Vista. Recife, PE, Brasil. CEP: 50-070-902. E-mail: marinaaustregesilo@gmail.com 4,7 Universidade Federal de Pernambuco. Recife, PE, Brasil.

\section{Abstract}

Objectives: to understand indicators of the social representation of the coronavirus in adolescents undergoing cancer treatment during the COVID -19 pandemic.

Methods: the theory of social representations was used as theoretical and methodological support in its procedural approach in an exploratory study of a qualitative nature. The free word association technique was used in the application of virtual forms using guidelines of the snowball method. The terms 'Coronavirus', 'Going to the hospital' and 'Cancer treatment' were applied. After that moment, the participants were asked for a hierarchy and justification of the evoked words. Data analysis was based on content analysis and frequency distribution of the content produced.

Results: articulations were made on the impacts that the pandemic situation had on the treatment experience of that population. It was identified a character endowed with fear and tension about the elaboration of the reality of these subjects in the current period in face of the inevitability of a hospital scenario that facilitates contamination and facing the immunological vulnerability characteristic of their treatments.

Conclusions: the participants constructed different contents of psychological suffering aimed at expressions of fear and insecurity experienced during the pandemic period in the face of assistance in the hospital setting. This study is understood as a contribution to more effective actions in order to adapt the care plan of this population, aiming at future professional interventions.

Key words Teens, Psycho-Oncology, SARS-CoV-2, Social psychology

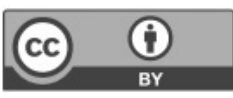




\section{Introduction}

The Coronavirus Disease 2019 (COVID-19) has been occupying a significant place in global attention, media spaces and consequently, in the daily dynamics of different social groups. ${ }^{1}$ Discovered in Wuhan, China, in December 2019, amidst a surge of respiratory diseases scenario, the new coronavirus presents a broad clinical spectrum, varying from a common cold to more severe cases such as the Middle East Respiratory Syndrome (MERS-CoV) and the Severe Acute Respiratory Syndrome (SARSCoV-2). ${ }^{2}$

The high number of oligosymptomatic and asymptomatic individuals, reaching over $30 \%$ of sick people, transmitters, in addition to the inexistence of vaccines and specific treatment and the insufficient coverage of testing made possible the global spread of the virus. ${ }^{3}$ Many countries adopted strict quarantine measures for the entire population, social distancing, and shut down of schools and universities, in order to avoid the health systems to collapse. 4

Such measures also bring other impacts in face of the radical routine change and the social distancing, demanding care to mental health - as well as to the psychosocial care - of the young and adolescent public. The experience of isolation can generate feelings of fear, uncertainties and anxiety that can affect wellbeing and quality of life dimensions. 5 The experience of fighting against a cancer consonant to the COVID-19 pandemic period expose patients in treatment to a high possibility of infection, with around $40 \%$ more chances of developing severe outcomes in face of an infection. 6

In addition to this, it is yet important to highlight the direct contact with hospital units, possible use of collective transport and scarce resources for personal protection such as masks and alcohol. Thus, a concern with the possibility of acquiring or disseminating the virus to family, friends and colleagues arises, issues that can directly affect mental health. ${ }^{7}$ These factors may result in different levels of psychological suffering, making this population vulnerable to feelings of insecurity about their lives, about going to hospital to continue treatment, as well as changes of perspective about their respective prognostics.

Given the above, the treatment against cancer becomes an even more sensible reality. Studies aiming to understand how these subjects in treatment comprehend their reality in face of pandemics of new coronavirus inspire care in from the scientific community. Studies points to, concerning social representations of diseases, a correspondence executed by subjects between social and biological dimensions of the experience of getting sick. ${ }^{8}$ The social representations which approach diseases and their treatment options make feasible the conception of social construction of meanings which guide experiences of patients considering their singular dimensions and social contexts in which they are set.

We aimed to comprehend indicators of Social Representation of the new coronavirus in young people going through cancer treatment in COVID-19 pandemic.

\section{Methods}

It is an exploratory, qualitative research, conducted by the mental health team of the Institute of Integrative Medicine Prof. Fernando Figueira (IMIP - Portuguese acronym). The target population of the study consisted in patients in cancer treatment - or up to one year after treatment conclusion - during the period of July 2010, in the course of COVID-19 pandemic, followed in reference hospitals in the state of Pernambuco. Without gender restriction; with age range of 18 to 24 years. The age range of the study population was defined within the interval established by the national youth policy. 9 The exclusion criterion was determined by the incompatibility with the eligibility criteria.

This process continues until the previously established measures for data collection, such as deadline for collection or maximum amount of interviewees, are accomplished, or for the occurrence of theoretical saturation, when new information on the data collected don't arise. 10 The form - using the free word association technique11 - consisted in three groups of evocations with the inductor terms "coronavirus", "going to hospital" and "cancer treatment" presented via the enunciations: "If I say 'coronavirus', what comes into your mind?"; "If I say 'going to hospital' what comes into your mind?"; "If I say 'cancer treatment', what comes into your mind?".

For each inductor term three answers were requested, generated from the free word association. After the moment of association the participant was requested to hierarchize the evocated words, and posteriorly to this organization exercise, a justification for that hierarchization was then requested.11 Finally, the participants answered a bio-sociodemographic questionnaire.

From the thematic Content Analysis 12 thematic categories were built from the justifications and free evocations, which were also categorized by simple 
frequency of manifestation and those considered the most important by the subject were listed. The participants were codified with the letter "P" and a correspondent number in order to ensure the preservation of secrecy. As theoretical contribution for analysis, the Theory of Social Representations was used. 13

A representation is conceived from: a mental, abstract representative of an object - which is reconstituted symbolically, reaching also the concreteness of the elaborating act and of tagging the subject in his/her activity - and the object. It is established a way of knowledge regarding the relationship between both of them, whose characteristics of the subject and object are constitutive. The activity of representing may indicate approximation to cognitive aspects or intra-psychic mechanisms, pointing to issues of the subject that are exclusively psychological.14 Analyzing social representations allows the comprehension of individual and group instances that guide the meaning of comprehension of a reality through its own reference system.

The research was conducted after being approved by the Ethics Committee - CEP/IMIP and or CONEP, under CAEE $n^{\circ}$ 34102920.5.0000.5201.

\section{Results and Discussion}

From the results of the forms, spontaneous evocations were collected, as well as the order of importance and justification for the words used for each of the three inductor terms. Thirty forms were answered, totaling 270 evocated words and 90 justifications for the group of three inductor terms, which were categorized separately.

The first part of the corpus presented results from the questionnaire with the inductor term "coronavirus". From the 90 words associated to the inductor term coronavirus, being ' $\mathrm{f}$ ' a representation of the frequency of each word, the most evoked were fear (f:8), isolation (f:7), disease (f:5) and care (f:3). The word disease appears as the most important one - ordained in first place - in five times, whist fear and isolation appear three times each.

From the content analysis of justifications, it was possible to identify five thematic categories present in total analysis corpus and to organize evocated words from these, being them Measures of care, Consequences of COVID-19, Evoked affects, Political scenario (Table 1) and Others.

Of the evocations total, 33 belong to the category Measures of Care, which contains words and justifications that describe manners of care and prevention to the COVID-19 infection, and among them, nine were considered the most important.

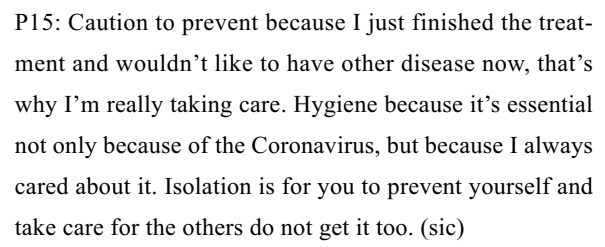

These care measures brought changes and losses in the quotidian of people, being related to feelings of danger and alertness, once even with the mentioned efforts the infection and mortality rates still rising. 15 During the evocations presented in this category it was possible to identify mentions such as: isolation, quarantine, alert, danger, protection, cleansing, care.

The mentioned changes have an even broader space in the quotidian of subjects in cancer treatment, for the therapeutic approaches used against cancer lead to impairments in immunity, placing them in a more vulnerable position.

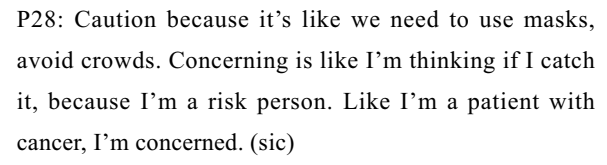

Possible consequences of COVID-19 were also mentioned and formed a category containing 12 evocations, among them symptoms and outcomes of the infection by the virus like disease (f:5), shortness of breath (f:2) and death (f:2).

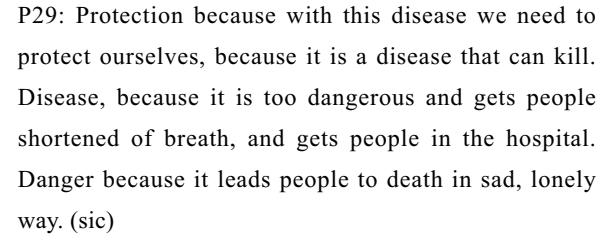

Inside this category it is pointed a certain domain of the study population regarding information published until now by the scientific community about the signs of manifestation of COVID-19 virus and its consequences to human organism. As seen in P9 speech "because it's the sequence of what I hear". The information points to a latent dimension over which a social representation is built. ${ }^{16}$ It refers to quality and quantity of subject's comprehension about the social object.

A category named "affects" was also built, containing 26 evocations concerning feelings and sensations retrieved by the pandemic, with a high- 
light for "fear" which appeared eight times. Words such as "sadness" (f:3), concerning (f:2), suffering (f:2), missing (f:2) and hope (f:2).

P5: Because I've been feeling a lot of fear of this disease and have become sad with all of this, all these deaths, without going out of home. (sic)

The goal of every social representation is making the unknown familiar. ${ }^{16}$ In the face of the pandemic scenario created by the new Coronavirus, this exercise can be perceived in the study population by means of the report of affects felt in the experience of living this period as a resource to describe and built it. This category reached the second highest frequency and such words as suffering, sadness, missing, hope, anger, loneliness and fear were evoked.

P26: fear because it is a disease without cure, no vaccine or unknown treatment because it is virus which can be everywhere and you don't know and get infected (...) I fear losing someone of my family, not seeing anymore (sic)

It is possible to understand this movement as an illustration of the anchoring process characterized by the insertion of the object of a social representation in a system of existing convictions drawing a network of significations around the unknown, attributing a meaning to it. 17 This activity allows the subjects to relate with the object coronavirus, placing it in a location which can be compared, for example, to diseases whose treatment and prevention are well known and accommodated in a safer manner in the subject's imaginary. In the moment of justification, contents like these were produced:

P11: Because of the fact that I've been having health complications the fear only increased, of suffering even more and increased the pains that I constantly feel, besides the fear of death that I can't help to feel. (sic)

Of the total of evocations if the inductor term coronavirus, 13 did not have correlations between each other and integrated the category "others". Besides, contents referring to discussions and latent issues in the political scenario arose, totaling five evocations composing this category.

P19: Sincerely, China because the virus came from there and chloroquine comes into my mind for being a drug that is not effective, but there is a lot of people advertising it (...) (sic)
In the second part of the corpus are the results obtained by means of the inductor term "going to the hospital". Of the 90 words, the most evoked were fear (f:9), exam (f:5), health (f:5), friends (f:4), care $(f: 3)$, consultation (f:3) and sad (f:3). The word fear appears as the more important one 4 times, whilst consultation appears three times.

From the content analysis of the justifications, three thematic categories were identified: Hospital scenario, Care and Evoked affects (Table 2). The Hospital scenario category brings together the highest number of free evocations, having 39 words, and is portrayed as the most important 13 times. It approaches descriptions regarding hospital quotidian, activities executed in this environment and sensations common to it, such as the routine of examinations (f:5) and hospitalization (f:2). The process of young and childhood cancer treatment is not rarely composed by a therapeutic follow up with long and wearing periods of alterations of routine in addition to constant visits to the hospital. 18

P19: Examination because I'm being assisted and not in treatment anymore, sleepiness because I live in the countryside and leave at the dawn chemotherapy because I spent 6 months having chemotherapy every 2 weeks being hospitalized for around 2 days (sic)

Many patients reported the need (f:2) for going to hospital for receiving cancer treatment (f:4) and maintaining it, which demonstrated to be related to the high risk of infection in face of the vulnerability peculiar to the treatment.

\footnotetext{
P15: Maintaining cancer treatment if we don't go to the maintenance consultation, the disease can come back and be even worse. Need because we in countryside only look for hospital when house medicine is not working, it is a necessity to take care of ourselves. (sic)
}

Fourteen words were also classified in the caution category, being the most important 6 times. In this category, the patients portrayed care (f:3) with health and prevention (f:2) of diseases because of the cancer treatment and the COVID-19 pandemic, such as use of masks (f:1) and alcohol (f:1).

P25: Caution because above all, even with or without coronavirus, I needed to double the caution to have the treatment successful. An infection like this can ruin years of treatment. Take the adequate cautions that the physician requests and above all, God's protection. (sic) 
The construction of a social representation houses a phenomenon of mediating function between a group of conceptions focused on social practices of a determined group and its individuals. 17 The reality of being in cancer treatment and need to attend to hospital environments during new Coronavirus pandemic inspired in the study group an expressive amount of evocations related to concerns with cautions in face COVID-19 pandemic grouped in "Care" category. Contents about preventive measures against COVID-19 infection were also previously mentioned in the categories of the inductor term "Coronavirus".

In 11 reports the patients points the relation between the easiness of getting sick during cancer treatment and the fear of being infected by the new Coronavirus. Patients with cancer have higher possibility of acquiring the coronavirus due to the vulnerability caused by the immunosuppressing effect that the disease and its treatment cause, which can compromise the overall health of the individual and lead to severe complications in face of COVID-19.19

The production of the latent contents evoked points indicators concerning the (re)built of subject's reality from information received from and about the coronavirus object expressed in concern to the high possibility of infection in the hospital context.

\footnotetext{
P4: Because I don't wanna get sick, afterwards any

disease will get me hospitalized and this can lead me to catch coronavirus, and symptoms because depending of what it is everything is bad, right? (sic)
}

Being social representation a construction of the subject about the object and not its reproduction, social representation can be understood as a productprocess by which a individual or group reconstructs the real to which he/her is confronted, conceding a particular signification to it. ${ }^{17}$ In the moment of the justification of importance of words, the participants produced observations in face of the possibility of infection.

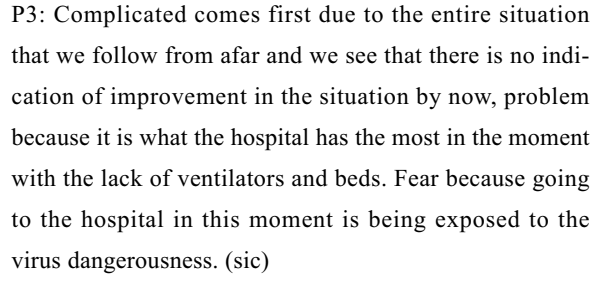

Another category that concentrates a high number of evocations was named Affects and it gathers contents referring to feelings perceived by patients when they need to go to the hospital. Fear (f:9) is largely portrayed by them.

P11: The fear of having another health complication, sadness because I need to be constantly in hospitals since 15 years hoping to get rid but the things that come to me always make me need to go and suffering because I already suffer a lot with all I've been through and so that I'm afraid of having anything more. (sic)

The experience of a pandemic may bring psychological and psychiatric repercussions. It was observed that fear behaviors brought both individual and collective impacts during Ebola outbreak, for example. Once it is an important defense mechanism to survival, not without fundament, fear arises in the evocations of participants. 15

Other affects are portrayed, such as sadness (f:3), stress (f:2), angst (f:1), suffering (f:1). We highlight here the psychological implications related to the new social dynamics imposed by Coronavirus. 1 The severity and uncertainties in face of the unknown common to this social phenomenon provokes affects such as fear, despair and dread, being these some of the words expressed by the participants. The participants mentioned directly angsts related to the sum of diseases in face of the possibility of infection by the new coronavirus, expressing indications of the mental representation of this object that, in this process, is (re)constructed symbolically.

P21: Fear of going to the hospital and maybe catch the coronavirus disease, or fear of going to the hospital and knowing that the cancer is back. Fear of the disease is back. Getting sick of a disease that no one knows exactly how it is. (sic)

For categories related to the inductor "cancer treatment" words and justifications concerning the treatment in a dissociate manner to the context of COVID-19 pandemic were evoked, which escapes from the aim of this article. The results referring to the terms "coronavirus" and "going to the hospital" were described and analyzed.

\section{Final considerations}

In the view of the above, it was possible to understand that the participant subjects of the research approached indicators of coronavirus social representation through the expression of the process of appropriation of the reality exterior to thought and elaborations of psychological and social approach. They built a particular comprehension by means of 
their own references in a movement of adaptation and (re)construction of their places inside social representations of this reality.

For the adolescents in cancer treatment or cure follow up, it was possible to highlight elements of construction of a reality in the pandemic period with character embedded with fear and tension in face of a hospital scenario that facilitates infection. We understand the research as a contribution for the theories of social thinking and, mainly, the compre- hension of diagnosis linked to social themes, in which the subjects could make clear elements regarding the manner as they signified this process, bringing possibilities of articulations about impacts that this conjuncture may generate in its treatments.

The results obtained may contribute to generate more effective actions in an attempt of adequate the care plan and following of this population, providing subsides for instrumentalizations of further professional interventions.

Table 1

Categorization of free evocations of the coronavirus describer with respective frequency and order of importance of each category and each evoked expression. Recife, 2020.

\begin{tabular}{|c|c|c|c|c|c|}
\hline Category & $\mathbf{F}$ & I & Expressions & $\mathbf{F}$ & $\mathbf{I}$ \\
\hline & & & Care & 3 & 2 \\
\hline & & & House & 2 & 1 \\
\hline \multirow[t]{4}{*}{ Measures of care } & 33 & 9 & Hygiene & 2 & 1 \\
\hline & & & Protection & 1 & 1 \\
\hline & & & Attention & 1 & 1 \\
\hline & & & Distancing & 2 & 0 \\
\hline \multirow[t]{3}{*}{ Consequences of COVID-19 } & 13 & 4 & Disease & 5 & 2 \\
\hline & & & Shortness of breath & 2 & 1 \\
\hline & & & Death & 2 & 0 \\
\hline \multirow[t]{6}{*}{ Evoked affects } & 26 & 7 & Fear & 8 & 3 \\
\hline & & & Suffering & 2 & 2 \\
\hline & & & Missing & 2 & 2 \\
\hline & & & Hope & 2 & 0 \\
\hline & & & Concerning & 2 & 0 \\
\hline & & & Sadness & 2 & 0 \\
\hline \multirow[t]{3}{*}{ Political scenario } & 5 & 1 & China & 2 & 1 \\
\hline & & & Bolsonaro & 1 & 0 \\
\hline & & & Chloroquine & 1 & 0 \\
\hline
\end{tabular}


Categorization of free evocations of the describer going to the hospital with respective frequency and order of importance of each category and each evoked expression. Recife, 2020.

\begin{tabular}{|c|c|c|c|c|c|}
\hline Category & $\mathbf{F}$ & I & Expressions & $\mathbf{F}$ & I \\
\hline & & & Treatment & 4 & 1 \\
\hline & & & Consultation & 4 & 1 \\
\hline \multirow[t]{8}{*}{ Hospital scenario } & 39 & 13 & Exam & 5 & 2 \\
\hline & & & Health & 3 & 2 \\
\hline & & & Necessity & 2 & 2 \\
\hline & & & Disease & 2 & 1 \\
\hline & & & To hospitalize & 2 & 0 \\
\hline & & & Wait & 1 & 1 \\
\hline & & & Obligation & 1 & 1 \\
\hline & & & Weariness & 1 & 1 \\
\hline \multirow[t]{3}{*}{ Care } & 14 & 6 & Prevention & 2 & 1 \\
\hline & & & Infection & 1 & 0 \\
\hline & & & Caution & 4 & 2 \\
\hline \multirow[t]{7}{*}{ Evoked affects } & 37 & 11 & Fear & 9 & 3 \\
\hline & & & Sadness & 3 & 0 \\
\hline & & & Positivity & 2 & 1 \\
\hline & & & Friends & 4 & 2 \\
\hline & & & Anxiety & 1 & 1 \\
\hline & & & Missing & 1 & 1 \\
\hline & & & Stress & 2 & 1 \\
\hline
\end{tabular}

\section{Author's contribution}

Silva MMAS conducted the research, data collection, methodology and results discussion, writing and review of the manuscript. Accioly $\mathrm{CC}$ and Pedrosa APA advisor and co-advisor of the research, writing of the project, data collection and results discussion. Azevedo SM performed the discussion of methodological aspects of research, writing and review of the manuscript. Albuquerque EN, Lima TLBK and Bouçanova MEP provided contributions in the writing and discussion of the research project. All authors approved the final version of the article. 


\section{References}

1. Bú EA, Alexandre MES, Bezerra VAS, Sá-Serafim RCN, Coutinho MPL. Representações e ancoragens sociais do novo coronavírus e do tratamento da COVID-19 por brasileiros. Estud Psicol (Campinas). 2020; (37): 1-13.

2. Saxena SK. Coronavirus Disease 2019 (COVID-19): Epidemiology, Pathogenesis, Diagnosis, and Therapeutics. Singapura: Springer; 2020.

3. Zhou F, Yu T, Du R, Fan G, Liu Y, Liu Z, Xiang J, Wang Y, Song D, Gu X, Guan L, Yuan Wei, Li H, Wu X, Xu J, Tu S, Yi Z, Chen H, Cao B. Articles Clinical course and risk factors for mortality of adult inpatients with COVID-19 in Wuhan, China: a retrospective cohort study. Lancet. 2020; 6736 (20): $1-9$.

4. Folha Informativa - COVID-19 (doença causada pelo novo coronavírus). Organização Pan-americana de Saúde. Brasília, 2020. [acesso 8 jun 2020]. Disponível em: https://www.paho.org/bra/index.php?option=com content \& view $=$ article\&id $=6101$ : covid $19 \&$ Itemid $=875$

5. Oliveira WA, Silva JL, Andrade ALM, Micheli D, Carlos DM, Silva MAI. A saúde do adolescente em tempos da COVID-19: scoping review. Cad Saúde Pública. 2020; 36 (8): 1-14

6. Brandes AA, Nunno V. How to face cancer treatment in the COVID-19 era. Expert Rev Anticancer Ther. 2020; 20 (6): 429-32.

7. Carneiro ES, Souza AIJ, Pina JC, Rumor PCF, Gevaerd TC, Cicéron MY. Abordagem da equipe de saúde nos agravos de saúde mental de crianças e adolescentes hospitalizados. Rev Soc Bras Enferm Pediatras. 2018; 18 (1): 7-14.

8. Apostolidis T, Fonte D, Aléssio RLS; Santos MFS. Representações sociais e educação terapêutica: questões teórico-práticas. Saúde Soc. 2020; 29 (1): 1-11.

9. Brasil. Projeto de Lei ${ }^{\circ} 4.530 / 2004$. Política nacional de juventude: diretrizes e perspectivas. Secretaria Nacional de Juventude. Brasília, DF; 2018.
10. Costa BRL. Bola de neve virtual: o uso das redes sociais virtuais no processo de coleta de dados de uma pesquisa científica. Rev Interdisciplinar Gestão Social. 2018.7 (1): $15-37$.

11. Coutinho MPL. A técnica de associação livre de palavras sobre o prisma do software tri-deux-mots. Campo do Saber. 2017; 3 (1): 219-43.

12. Bardin L. Análise de conteúdo. 1 ed. São Paulo: Edições 70; 2011. 279 p.

13. Moscovici S. A representação social da psicanálise. Rio de Janeiro: Zahar Editores; 1978.

14. Jodelet D. Representações Sociais: Um domínio em expansão. In: Jodelet D, organizators. As Representações Sociais. Rio de Janeiro: EdUERJ; 2001. p. 17-44.

15. Ornell F, Schuch JB, Sordi AO, Kessler FHP. Pandemia de medo e COVID-19: impacto na saúde mental e possíveis estratégicas [Editorial]. Rev Debates Psychiatry. 2020.

16. Moscovici S. Representações sociais: investigações em psicologia social. Petrópolis: Editora Vozes Ltda; 2003.

17. Santos MFS, Almeida LM. A teoria das representações sociais. In: Santos MFS, Almeida LM, organizators. Diálogos com a teoria da representação social. Recife: Ed. Universitária UFPE; 2005. p. 15-38.

18. Hora SS, Monteiro MVC, Dias SM, Lima FFS, Silva JA Acesso e Adesão ao Tratamento Oncológico Infantojuvenil: para além do aspecto médico-biológico. Rev Bras Cancerol. 2019; 64 (3): 405-8.

19. Rodrigues AB, Vieira AA, Santos SGC. Medidas de Prevenção e Manejo Adequado do Paciente Oncológico em Tempos de Covid-19. Rev Bras Cancerol. 2020. 66 (e1125): 109-18.

Received on September 29, 2020

Approved on December 13, 2020 